\section{A REFLECTION OF THAI CULTURE IN THAI PLANT NAMES ${ }^{1}$}

\section{Unchalee Singnoi $^{2}$}

\begin{abstract}
The present study focuses on the plant naming system in the Thai language based on 1) Brent Berlin's general principles of categorization of plants and animals in traditional societies (Berlin, 1974, 1992) which suggest that it is worthwhile to think about a plant taxonomy system on the basis of plant names since the names provide the valid key to folk taxonomy and 2) Lakoff's central guiding principles of cognitive linguistics (Lakoff and Johnson, 2003 and Lakoff 1987). Data on plant names collected from printed materials are selectively analyzed. The study examines the linguistic structure, folk taxonomy and conceptualization of plant terms in the Thai language. It is found that there exists in the Thai language a complex and practical plant naming system establishing a relationship between language, cognition and culture.
\end{abstract}

\section{Introduction}

The term "plant names" in the paper refers to a particular linguistic structure people commonly use to call a variety of plant life. A common plant name may convey

\footnotetext{
${ }^{1}$ The research project was funded by the Faculty of Humanities, Naresuan University. The support is herewith again gratefully acknowledge.

${ }^{2}$ Assoc.Prof.Dr., Department of Language and Folklore, Faculty of Humanities, Naresuan University, Thailand
}

only the core name that can differentiate one plant from another or include other parts people add to the core to depict that particular form of plant life. The common names of plants often vary from region to region, which is why most plant encyclopedias refer to plants using their scientific names: binomials, or "Latin" names. It is not unusual that many plants to have several common names, and for many common names to refer to several distinct plants.

In the last decades, a number of research works have investigated the plant naming systems of traditional societies from biological, ecological, anthropological, linguistic, cultural and social perspectives, focusing either on the structure of naming or the categories of the identities they intend to describe. Quite a lot of literature has been written about the different levels of classification, semantic features and cultural implications of the naming system. A pioneer group of researchers dealing with the structure of plant and animal naming includes Berlin, Breedlove and Raven (1973, 1974, 1992). These papers, in which general principles of folk taxonomy were elaborated based on ethnobotanical studies in Central and South America, drew convincing parallels with the taxonomic thinking among European people, which became the basis of taxonomy in Western science. At the core of Berlin's argument is the five-level structure of the taxa or taxonomic group, called taxonomic ethnobiological categories. These smaller categories are defined in terms of certain criteria, such as having certain linguistic or taxonomic features that are recognizable. The five ethnobiological categories are as follows: unique beginner, life form, generic, specific, and varietal. Most, if not all organisms, flora or fauna, can be placed 
taxonomically into these categories. This is a specifiable and partially predictable set of plant and animal taxa that represent the smallest fundamental biological discontinuities easily recognized by any particular habitat. That is, people tend to categorize in predictable ways based on recognizable differences in the environment around them. Years later, several research papers in ethnology followed Berlin's principles as the best available system to present ethnotaxonomic data (Hiepko 2006).

As claimed in Berlin (1992), traditional taxonomic groupings of plants and plant names have been assigned in sensible patterns. Understanding the patterns provides insights into the cultural perspectives and evolutionary histories of those who developed the groupings and names. This claim is in accordance with researchers in cognitive linguistics such as Lakoff and Johnson (2003) and Lakoff (1987), who have worked on the assumption that language is the outcome of general properties of cognition and that conceptual representation is the outcome of the nature of the bodies humans have and how they interact with the geolinguistic and socio-physical world. The experience of Thai people can explicitly demonstrate these ideas. The Thai plant naming system does share some of the features proposed by these researchers, but in the author's observation, there is more to it than that. There is a specific way in the Thai language of naming plants, and this will be discussed in detail in the following sections.

For the purpose of this paper, I focus on morpho-syntactic patterns of lexical and grammatical systems of nominal classification, categorization systems and folk conceptualization illustrated in plant names in an attempt to explicate their roles. Here, Thai plant names are generally investigated. More than 3,000 plant names were collected from a number of reliable sources such as plant encyclopedias, localdialect dictionaries, local plant taxonomy and classification, plant collections, and other printed materials by academic institutes in all four main dialects of Thailand: North, Northeastern, Central and South. The choice of entries is richness of Thai folk terms for plants in all four main regional forms, both wild and cultivated, but excluded are:

1.) words that merely refer to a plant part; for example, hǔa-plii referring to banana tree flowers.

2.) words that refer to the state of a plant, for example, nò-máay referring to young bamboo or bamboo shoots.

\section{Background on Class Terms, Classifiers and Class Markers in the Thai Language}

One of the research aims is to investigate plant names in Thai and their linguistic role as a system of nominal classification. In general, systems of nominal classification have typically been described in terms of three sub-types: 1) lexical system (class terms and measures), 2) lexico-grammatical system (classifiers), and 3) grammatical system (noun class markers and gender). However, the terminology used to discuss nominal classification systems typologically is not consistent in the literature. In particular, quite a number of researchers tend to use the term classifier to describe both lexicogrammatical and grammatical systems of classification. For the purposes of this paper, I use the term nominal classification 
as a broader cover term to mean a system through which language and its native speakers mark nouns based on categories, which would include class terms, classifiers, and class markers. Many researchers have put more focus on noun classifier systems in the last decades (see Craig 1986, and references therein). Concrete nouns are categorized according to intrinsic/generic characteristics, perceptual features, including most prominently animacy, shape, and consistency (Adams and Conklin 1973). A less well studied type of categorization is found in class terms, noun roots of a relatively general sense that occur in compounds with a categorizing function (DeLancey 1986 and Beckwith 1993). In Thai, the class term and classifier systems have been differentiated in the literature (cf. Singnoi 2008) but the noun class marker system has not.

For a brief orientation of nominal classification involving Thai plant names, it is much more convenient to begin with the syntactic scope of noun classifiers which is much more well-known. Then the other two categories are compared to see the syntactic difference. Thai is a good example of the numeral classifier languages which require the classifier morpheme in order to code the quantity of a noun (hereafter N) as many South and East Asian languages do. Thai is classified as an isolating language which exhibits a type of SVO language and the headmodifier noun phrase. The language is also well known for its elaborate classifier system. The classifiers are good examples of morphemes which differentiate entities into different classes, both generally and specifically, and manifest native speakers' cultural beliefs by noun categorization.
Synchronically, the Thai noun classifier construction $^{3}$ consists of quantifier/numeral (hereafter Q) followed by a noun classifier (hereafter CLF), forming a sequence of constituents:

(1) $Q+C L F$

The head noun can either precede or follow the compound constituent, as shown respectively:

(2) măa š̌ọ tua dog two CLF (animal/body) 'two dogs'

(3) sǒoy kon phǔa mia two CLF(human) husband wife 'two people, a husband and wife'

However, the second compound constituent is limited to a combination of human head nouns with a certain relationship such as spouse (e.g., husband and wife, grandfather and grandmother) and kinship (e.g., father and son/daughter, mother and son/daughter, older brother/sister and younger brother/sister) while it is prohibited to non-human (Singnoi 2000).

Apart from classifiers, Thai presents another type of classification called class terms (CLT), as proposed by Delancey (1986) in his study of Thai classifiers with reference to the work of Haas in 1942. Class terms do not function as true classifiers. They classify nouns by cooccurring with the classified nouns in a large number of compound words (Singnoi 2005 and 2008). The study of Thai

\footnotetext{
${ }^{3}$ For details of the project Classifier

Construction in Thai, see Singnoi (2008), which also includes its semantic and pragmatic aspects.
} 
nominal compounding by Singnoi (2005) reveals that lexicalized compound nouns in the pattern noun-noun, like fayfâa (firesky) 'electricity', lǔuk-nâam (offspringwater) 'mosquito baby' and so forth, allow class terms to act as the heads in the first position which semantically classify the following noun constituents in terms of features or shapes like classifiers, as shown below:

(4) kôon-hĭn

CLT (lump shape)-stone

'a lump of stone'

(5) sên-thaạ

CLT (line shape)-path

'a route'

(6) lûuk-bon

CLT (small round shape)-ball

'a ball'

However, class nouns as such do not function like pure classifiers. Thus consider:

(7) lam-thaan

CLT-brook

'brook'

(8) *lam-thaan CLT-brook

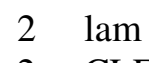

(9) lam-thaan

CLT-brook

2 hæ̀n

2 CLF for place

In the examples above, the class term lam generally classifies objects into the longand-round-shaped group, but it does not always occur as the classifier of a longand-round-shaped head noun, which hæi is a classifier for place, does. Therefore, the difference between class terms and classifiers would obviously be predicted on the grounds that class terms occur with their classified nouns (which are their subordinate terms) in lexicalized compounds, while classifiers occur with their classified terms in other syntactic constructions, so that it is perhaps unnecessary to connect this with any significant difference in semantic function. This is in accordance with Saul (1965) who provides a description of Nung, showing the syntactic distinction of the two similar categories. That is, class terms are obligatory (indeed lexically bound) components of their compounds, while classifiers occur only under specific syntactic/semantic conditions.

In the CLT-noun compound, even though the class term head is modified by its subordinate term, it is not equivalent to what Rosch (1977) called the hypernym of the superordinate term which is a basiclevel term (which is an ordinary noun) in the sense that class terms are not necessarily independent while basic-level terms are, as shown in the examples below.

(10) Class term: lam 'long-and-roundshaped object'

* mii lam măy have long-and-round-shaped object Q 'Is there any long-and-round-shaped object (here)?'
(11) Basic-level term: plaa 'fish'
mii plaa mǎy
have fish $Q$
'Are there any fish (here)?'

The other categorization system involving Thai plant names is noun class markers. Some typical characteristics of noun class markers have been provided by works such 
as Dixon (1986) and Aikhenvald (2003). They provide that noun class markers classify all the nouns in a language while class terms are lexically bound and classifiers vary in boundedness crosslinguistically ${ }^{4}$. Dixon (1986:106) claimed that noun class markers typically emerge as affixes, grammatical words, or clitics. They tend to denote "such core semantic characteristics as animacy, sex, and humanness".) Accordingly, Grinevald and Seifart (2004) have stated that noun class markers occupy positions on a typological continuum, reflecting a diachronic pattern of language change from class terms to noun class markers of agreement or gender. Class markers are widely studied in African languages, some of which exhibit several classes (for example, see late work in Legère 2004 illustrating 11 noun class markers in Vidunda, a Tanzanian language). In Thai, it seems that class terms and noun class markers, occurring in the positions before plant names, are extensively used to identify plant life. However, folk plant names are among rare language cases that still exhibit another grammatical category called noun class markers/gender in Thai. The examination of folk plant names, therefore, is of great benefit in understanding the conceptualization of the Thai classification system.

\section{Linguistic Structures of Thai Plant Names}

Like other languages, even though there are scientific terms such as "Echinochloa colona", the Thai language does have a system of its own. The linguistic system of

\footnotetext{
${ }^{4}$ However, the boundedness of class terms and classifiers is still debatable. Conflicting findings on their function as independent nouns within classifying languages are discussed in Henerson (2006)
}

plant names in the Thai language is quite complex compared to other names such as those for people, locations, objects and so on. That is, the plant names can be mentioned in two alternative ways: plain and complex structures. The first is more typical whereas the later is specifically found.

\section{Plain Structure}

The plain structure of the nouns or noun phrases in traditional Thai is HEAD + MODIFIER, where the head optionally combines with one or more modifiers. This structure is also relevant for the plain structure of plant names:

$$
\text { (12) } \mathrm{CORE}+(\mathrm{MOD})+(\mathrm{MOD})
$$

Accordingly, names consist of the core or head, which is either simple or complex (compound, nominalized, or reduplicated form), and one or two optional modifiers, whether simple or not. Here are some examples which represent various types of Thai plant names. The CORE is on the left (if there is one or two modifiers), and the two optional MODS (if both of them appear) are on the right separated by ' + ' from the CORE. Word constituents in a complex form are separated by '-'.

(13) Simple core:
campii
'Magnolia $x$ alba'

(14) Compound core:

phîi-ŝ̀a

butterfly (lit.: ghost-shirt)

"Alangium chinense"

(15) Nominalized core from a noun phrase: mǎa-dam dog-black 'Miliusa cuneata' 
(16) Nominalized core from a clause: Yaay-cuun-lăan grandma-lead by the hand-grandchild 'Myrsinaceae paniculata'

(17) Reduplicated core: tòt-mǔu tòt-măa fart-pig fart-dog pig's fart dog's fart 'P.linearis'

(18) Simple core + a simple modifier: yoo + pàa Morinda citrifolia forest 'Morinda tomentosa'

(19) Simple core + a complex modifier: salăw + [plłak +baay] Lagerstroemia tomentosa bark thin Lagerstroemia tomentosa thin bark 'Lagerstroemia venusta'

(20) Simple core + two simple modifiers: kòs + mǔu + doวy Castanopsis pig hill 'Castanopsis calathiformis'

\section{Complex Structure}

However, people often call plants in a more complex way, attaching one or more class terms and class markers to the left of the core. In the first position, the generic class term (GNCLT) tôn 'plant stalk' could be attached to plant names, similar to certain English plant names such as cotton wood, banana tree, China box tree, rain tree, and so on. It applies to any kind of plants whether they are trees, shrubs, creepers, or bulbous plants. Even though Thai has the higher class term phîtt 'plant' for all kinds of plants, it is tôn that functions to identify the plant kingdom. Below is an example of this case:

$$
\begin{aligned}
& \text { (21) GNCLT }+ \text { CORE } \\
& \text { tôn campii } \\
& \text { stalk Magnolia x alba } \\
& \text { 'Magnolia } x \text { alba' }
\end{aligned}
$$

People can also classify plants from the perception of plant parts that are salient or useful to them, resulting in another slot of class terms called plant part class terms (PPCLT) in this research, as shown below:

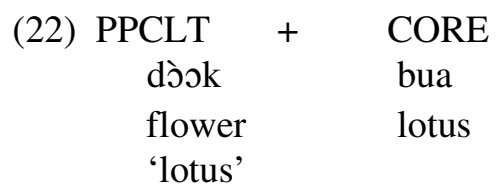

Both the GNCLT and PPCLT can occur simultaneously. When they do, the GNCLT ton leads the PPCLT as shown below:

$$
\begin{aligned}
& \text { (23) GNCLT + PPCLT + CORE } \\
& \text { tôn dòok baan-yen } \\
& \text { stalk flower marvel-of-Peru } \\
& \text { 'marvel-of-Peru' }
\end{aligned}
$$

However, the co-occurrence of the GNCLT and PPCLT is not typical. While example (23) is fine, it is not acceptable for the plant name in example (22) to convey the GNCLT. Also, it is not necessary for all Thai people to agree that the GNCLT can lead certain plant cores especially plants without stalks or bulbous plants, as shown:

$$
\begin{array}{ll}
\text { (24) ? tôn hǔa } & \text { hâw } \\
\text { stalk bulb } & \text { water chestnut } \\
\text { 'water chestnut' } &
\end{array}
$$

Another class term slot found in this research is functional class terms (FCLT), which reveal the roles that plants have or the purposes for which they are used. Their appearance results in an additional 
slot to the right of the former types in the plant name structure as exemplified below:

$$
\begin{array}{ccc}
\text { GNCLT } & \text { FCLT } & \text { CORE } \\
\text { tôn } & \text { máay } & \text { pray } \\
\text { stalk } & \text { wood } & \text { necked } \\
\text { 'Lagerstroemia cochinchinensis' }
\end{array}
$$

(Another Thai name is tôn tabæææk, a kind of tree which has a necked stalk, big leaves and purple flowers)

$$
\begin{array}{ccc}
\text { (26) } \begin{array}{l}
\text { PPCLT } \\
\text { kła }
\end{array} \quad \text { FCLT } & \text { phàk } \\
\text { vine } & \text { vegetable } & \text { kâæp } \\
\text { Kap } \\
\text { Melothria heterphylla; Coccinia indica' }
\end{array}
$$

(Another Thai name is tamlin , a kind of vine which is viewed as vegetable and herb)

Beside the three CLTs, there are two bound morpheme types functioning as class markers in the slots following the CLTs. The first type immediately following the FCLT is má? 'fruit' for plants that have fruit, and therefore the fruit class marker (FRCLM) in this paper. Examples are shown below:

\section{(27) $\mathrm{FCLT}+$ FRCLM + CORE phàk má? hòoy vegetable fruit Momordica- 'Momordica charantia linn charantia linn. (bitter melon small)'}

The other class marker type includes a number of morphemes marking for gender, thus gender class marker (GDCLM). This class marker type follows the FRCLM or prefixes immediately to the core, as exemplified below:

\author{
(28) FRCLM + GDCLM + CORE \\ má? ?ii hum \\ Fruit FEMALE Moringa- \\ oleifera \\ 'Moringa oleifera (hourse-radish tree)'

$$
\begin{aligned}
& \text { bàk khôok } \\
& \text { MALE Siphonodon- } \\
& \text { celastrineus } \\
& \text { naay lák } \\
& \text { FEMALE Ocimum- } \\
& \text { citriodourum } \\
& \text { 'Ocimum citriodourum } \\
& \text { (hoary basil)' }
\end{aligned}
$$$$
\text { 'Siphonodon celastrineus' }
$$

The co-occurrence of class terms and class markers is possible as can be seen in some of the examples above. A plant name can optionally convey either up to three class term slots or two class marker slots. It is also possible that both class terms and class markers, though not all, can appear simultaneously in the same plant names. An example is provided in (31) for the first case. The second case can be seen in (28) which is repeated in (32) for the sake of convenience. The last case can be seen in (27), and more examples can be shown in (33) below.
(31)GNCLT+PPCLT+FCLT+CORE+MOD1 tôn hǔa phàk kàat khăaw stalk bulb vegetable Kat white 'turnip'
(32) FRCLM + GDCLM + CORE má? Pii hum fruit FEMALE Hum 'Moringa oleifera (drumstrick tree)'



(33) FCLT + GDCLM + CORE phàk lii lât vegetable FEMALE Lert 'Piper sarmentosum'

The discussion so far has portrayed the complex structure of Thai plant names. A schematic representation of the complex structure of plant names is as follows:

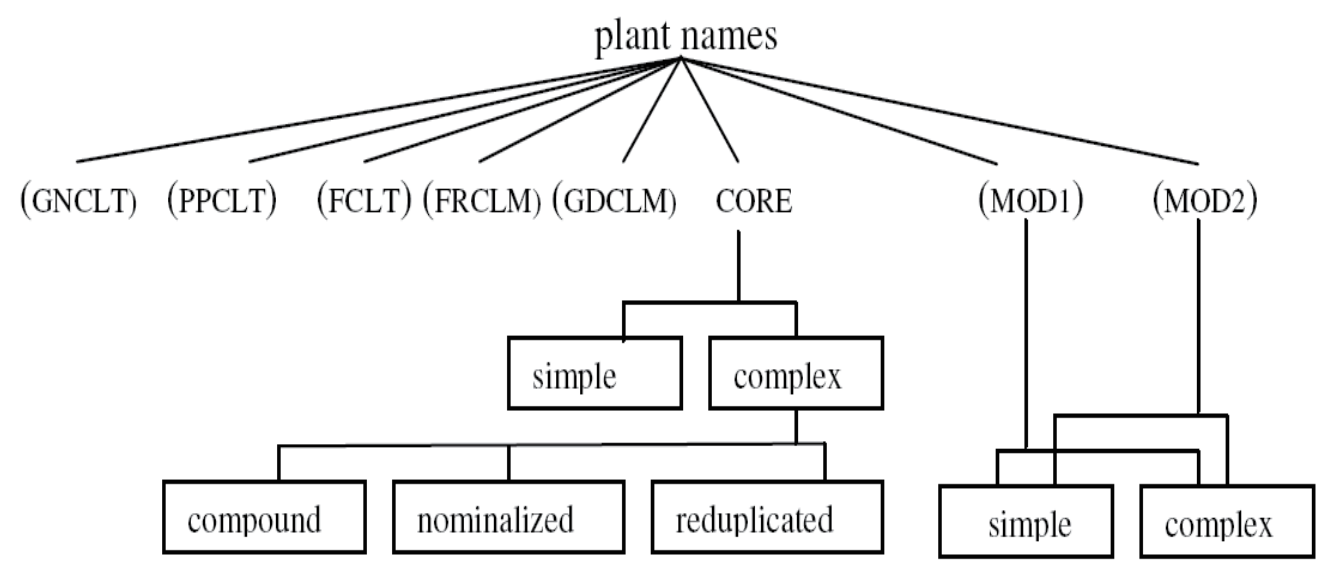

The diagram above that a plant name can appear as the potential CORE solely, which is in either a simple or complex fashion portraying compound, nominalized, or reduplicated form (as exemplified in (14), (15), and (17) above). A core can be modified by one (MOD1) or two modifiers (MOD1 and MOD2), which are whether simple or complex. In addition, a plant name may optionally convey one or more class slots such as class terms (GNCLT, PPCLT and FCLT) and class markers (FRCLM and GDCLM).
Categorization and the Folk BioTaxonomic System of Thai Plant Names

Categorization may be based on scientific or scholarly methods and principles or they may be based on social and cultural transmission. ${ }^{5}$ Folk taxonomies exist to allow popular identification of classes of objects, and apply to all areas of human activity. All parts of the world have their own systems of naming local plants and animals. These naming systems are a vital aid to survival and include information such as the fruiting patterns of trees and the habits of large mammals. These localized naming systems are folk taxonomies. Folk taxonomies are

\footnotetext{
${ }^{5}$ For the latter, a piece of evidence can be seen in DeLancey (1998) that the categorization in Tibetan honorific nouns is social and cultural rather than perceptual.
} 
generated from social and cultural knowledge that is embedded in the cognition. They are distinguished from scientific taxonomies that claim to be disembedded from social relations and thus objective and universal. For the sake of plant nomenclature, it is urged that scientific names facilitate communication about plants; common/folk names confuse communication. On the other hand, common names have no standardization at all and vary from person to person, region to region, and country to country.

The Thai folk plant taxa are of several distinguishable types, the so-called ethnobotanical ranks. The linguistic consideration above reveals five ranks of the Thai ethno-botanical system, as illustrated in the following figure.

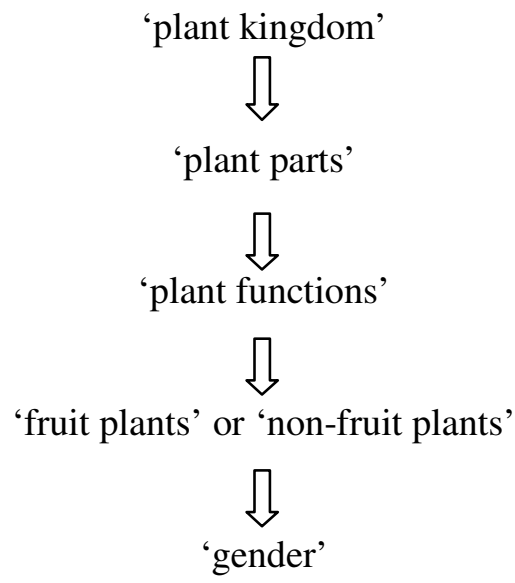

\section{Plant Kingdom Rank}

Similar to English, this rank is named phîtt 'plant'. Thai people can rapidly distinguish plants from animals. Unlike English and some other folk plant classifications; e.g., Eipo $^{6}$ plant classification (Hiepko 2006), the

\footnotetext{
${ }^{6}$ Eipo are a small group of people living in several villages in Eipomek valley in the Central Highlands of Irian Jaya. (Hiepko 2006)
}

rank includes fungi, defined in the Standard Thai Dictionary (Royal Academy of Thailand 1999) as a kind of mushroom or plant that has no chlorophyll, root, stalk, or leaves. However, the term phît never appears in plant names. It is the other competitive term tôn 'plant stalk', the most important part of most plants, that metonymically functions as the highest term in the classification.

\section{Plant Part Rank}

Thai people distinguish several taxa via salient plant parts and plant parts that are useful to them. It is found that the parts, at least, include blossom (d’̀ok), leaf (bay), fruit (lûk, nǔay), pod (fák), branch (kâan), stem (kì)), lower stalk (kòk, khoon, too), vine (khrła, thăw/thăwwan, yâan), tuber (hǔa), bulb (nう̀)), thorn (năam, sîan), spike (ruay, raay), and hair (phǒm, khǒn). A list of examples is shown in the structure plant part-core names below:

(34) dòok-din

(blossom-Burmannia coelestis)

(35) bay-châaphluu

(leaf-Piper sarmentosum)

(36) lûuk-yoo

(fruit-Morinda citrofolia)

(37) fâk-phráa

(pod-Canavalia gladiata/ sword-bean)

(38) kâan-khว̌on

(branch-Millingtonia hortensis)

(39) kì-hăay

(stem-Crotalaria labunifolial)

(40) khoon-samว̌ว

(lower-part stalk-Vitex pinnata)

(41) khrı-khǎwhôo

(vine-Tinospora cordifolia)

(42) hǔa-krathiam

(buber-Allium sativum/ garlic) 
(43) nòo-krathıt

(bulb-Aingiber zerumbet)

(44) nǎam-yáp

(thorn-Minosa pudica)

(45) ruaj-say

(spike-Buchanania siamensis)

(46) phǒm-yó?

(hair-Nephlium lappaceum/ rambutan)

\section{Functional Rank}

Thai people sometimes further classify plants from the perspective of plant function, i.e., plant roles or the purposes for which they are used. Plants are subdivided into a number of subclasses revealing the ways people use plants such as edible plants (phak 'vegetable'), main food (khâaw 'rice'), building materials (máay 'wood'), medicinal plants (wâan, phlay 'herb), sacred plants (phayaa, khǔn, mahăa 'human honorific titles'), and useless plants (yâa 'grass'). A list of examples is shown in the structure plant function-core names below:

(47) phàk-chii

(vegetable-Coriandrum sativum)

(48) khâaw-phôot (rice-corn)

(49) máay-dææn

(wood-Wylia kerrii/ ironwood)

(50) wâan-hăaycoorakhêe

(herb-Atoe indica)

(51) phayaa-má?khǎampôom

(honorific title-Dacrycarpus imbricatus)

(52) yâa-phræ̂æk

(grass-Cynodon dactylon)

\section{Fruit Plant Rank}

Thai people obviously categorize fruit plants from other plants by marking those plant names with the prefix máp. There is evidence that the morpheme má? has diachronically gone through some phonological and semantic changes from the PPCLT maak 'fruit' with the lose of the final consonant $/-\mathrm{k} /$ to a prefix to the core of plant names. For instance, má Pkhăam (tamarind), a kind of fruit in the Central Thai dialect, is called màakkhăam in other Thai dialects such as the Northern and Northeastern Thai dialects. Furthermore, its semantic content has been bleached or faded over time, and thus it is not necessary to refer to only fruit. Rather, the co-occurrence refers to all fruit plants including certain plants that do not have (edible) fruit, like má $2-k h a ̂ a$ 'Afzelia xylocarpa'.

\section{Gender Rank}

Similar to humans, plants are also categorized into different sexes: male and female. Some of them also present a Thai dialect factor. The gender markers include iii- 'female', naay- 'female', bak-/bà?'male (Northeastern Thai dialect), and bay- 'male' (Southern Thai dialect).

53) ?ii-krathıt

(female-Aingiber zerumbet)

(54) naay-lák

(naa)-Ocimum basilicum

(55) bàk-phîlaa

(male/Northeastern Thai-Punica granatum)

(56) bay-krà?

(male/SouthernThai-Elateriospermum tapos)

\section{Folk Conceptualization of Thai Plant names}

Thai conceptualizations of plants as manifested in plant names afford a good deal of subtlety in their semantic structure. The nomenclatural situation is somewhat complex due to extensive uses of imaginative language expressions from 
people's experiences. In this respect, it is the core and modifiers which are candidates to exhibit the folk conceptualizations of the world around them. The nomenclatural situation is somewhat complicated due to local extensive and taboo systems responsible for a multiple naming of many plants. For instance, there are a number of local extensive names for an odoratum (or Bitter bush, Siam weed) called sàapš̌a (tiger smell) and a taboo name for a kind of egg plant called kháa-yaaw 'aubergine long green'. Only the more common names sàapš̌a and má̃- khғ̌a-yaaw can be used for a comparison with other systems. However, the synonymous local names are also of interest because they are linguistically analyzable and reveal some folk conceptualizations of plants, as illustrated below.

Some of the descriptive names for sàapš̌a 'tiger smell' are:

$$
\begin{array}{ll}
\text { hǔuša } & \text { 'tiger ears' } \\
\text { hǔaša } & \text { 'tiger head' }
\end{array}
$$

(60) šamòop 'tiger lying prostrate' khîilôs 'mule dung'

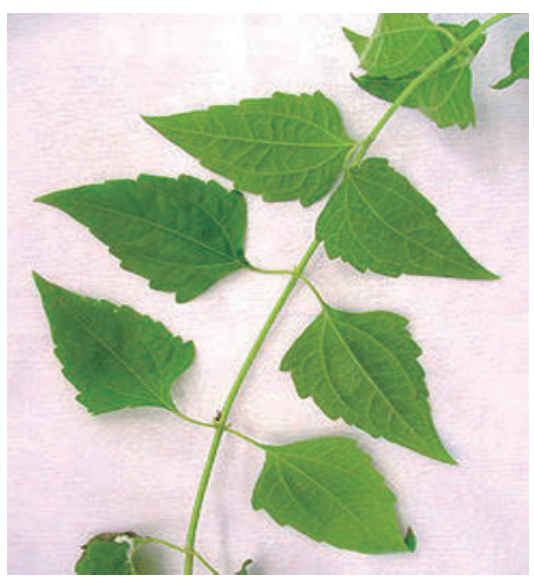

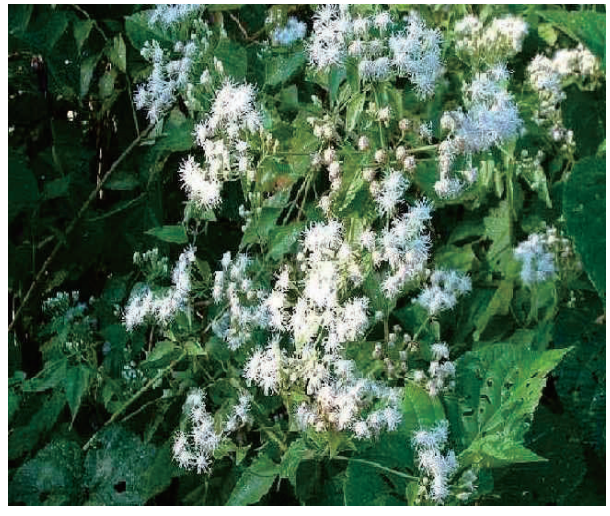

(th.wikipedia.org)

A more descriptive names for má̂- khғ̌ayaaw 'aubergine long green' is:

(61) (má2-)khł̌a-hămmá 'horse penis'

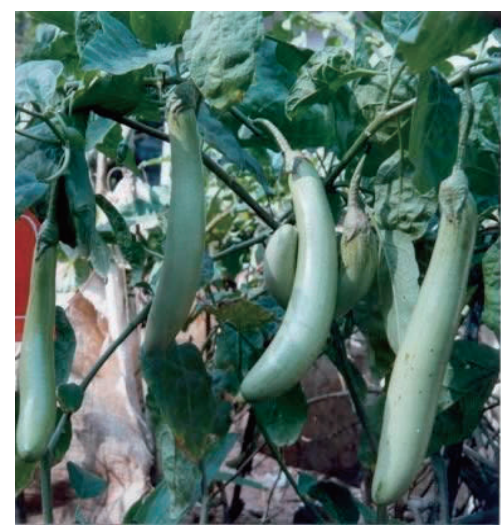

(www.vegetweb.com)

The following table illustrates the percentage of meaning categories of the core $(1,890$ names) and the modifier parts ( 1,350 words). In fact, it is the modifiers that relatively reveal what people think when they are talking about plants since they display more imaginative uses than the cores. 
Table 1. Meaning Categories of the Core and Modifiers and Percentage of Occurrence

\begin{tabular}{|l|l|l|l|}
\hline Core & Modifier \\
\hline Meaning categories & Percentage & Meaning categories & Percentage \\
\hline Proper names & 63 & Metonymical uses & 61 \\
\hline Metaphorical uses & 27 & Metaphorical uses & 24 \\
\hline Metonymical uses & 10 & Proper names & 15 \\
\hline & 100 & & 100 \\
\hline
\end{tabular}

While $63 \%$ of the cores display proper names, for example, tabæ̀æk 'Lagerstroemia cochinchinensis', salăw 'Lagerstroemia tomentosa', wâa 'Syzygium cumini', ...etc., only $15 \%$ of the modifiers are found as proper uses, for example, tææy-kwaa 'cucumber', sômPoo 'Citrus grandis (pomelo)', buฤăalamciak 'Goniothalamus tapis', ...etc. 85 $\%$ of modifiers display imaginative uses: $61 \%$ are metonymical uses and $24 \%$ are metaphorical uses (as exemplified in (62) and (63) below), while $37 \%$ of the cores display imaginative uses: $27 \%$ are metaphorical and $10 \%$ are metonymical. These differences are discussed in the following sections.

\section{Plant Name Cores}

It is found that at least $37 \%$ of the core names display imaginatively used words in the metaphorical (c.27 \%) and metonymical types (c.10\%). Other names (c. $63 \%$ ) are proper names which are usually monomial and linguistically not analyzable synchronically. Below are examples of plant names which obviously illustrate the two types of imaginative categories.
62) Metaphorical name:

tôn + nom-yua

tree cow's breast

'Coniothalamus laoticus'

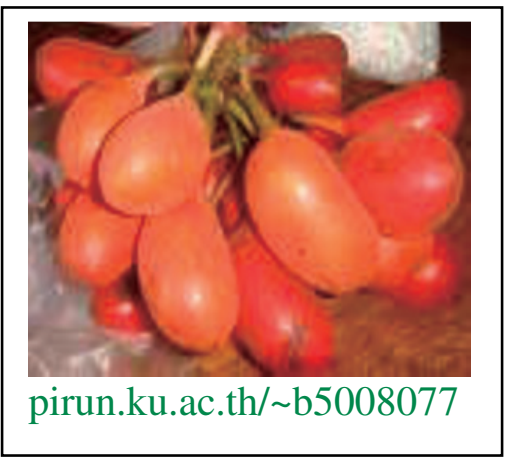

(63) Metonymical name:

tôn + yaay

tree resin

'Dipterocarpus (rubber tree)'

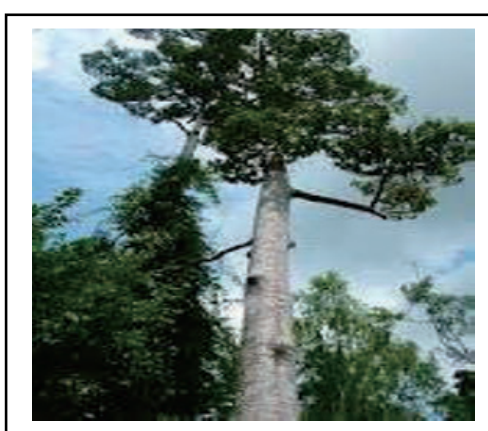

Takuyak.com 
The metaphorical names pertain to several source domains plants are attributed to. It is found that the source domains would be categorized as human/ human parts, animal/ animal parts, other plants, nature, places, beliefs, auspicious/ propitious things, objects and excrement. Among the core names, it is the animal or animal part domain that the majority of plant cores are found pertaining to. The human/ human part domain is in the second rank which is not far more than the third rank, object domain, and the fourth rank, auspicious/ propitious things. Excrement, nature, and other plant domains are less imaginative than the former ones but more imaginative than the god/ghost and place domains, as shown in table 2 below:

Table 2. Categories of Metaphorical Source Domains of the Core and Percentage of Occurrence

\begin{tabular}{|l|c|}
\hline $\begin{array}{l}\text { Categories of source } \\
\text { domains }\end{array}$ & Percentage \\
\hline Animals/animal parts & 38 \\
\hline Humans/human parts & 16 \\
\hline Objects & 13 \\
\hline $\begin{array}{l}\text { Auspicious/ Propitious } \\
\text { things }\end{array}$ & 11 \\
\hline Excrement & 8 \\
\hline Nature & 7 \\
\hline Other plants & 4 \\
\hline Gods/ghosts & 2 \\
\hline Places & $\mathbf{1 0 0}$ \\
\hline Total & \\
\hline
\end{tabular}

Below is a selection of plant cores which are obviously derived from other word categories (displayed on the right).

(64) tiin-pèt animal part feet-duck 'Alstonia scholaris'
(65) farày
human
foreigner/westerner
'Psisium guajava (Guava)'

(66) krabooy-phét object

club-diamond

'Cereus hexagonus (Cactus)'
(67) hǔa-wæ̌æn propitious things head/top-ring
'Decaspermum parviflorum'
(68) khîi-nว̌on excrement dung-worm
'Schoepfia fragrans'
(69) can-thoon nature moon-gold 'Fraxinus floribunda'
(70) khâaw-sǎan other plant rice-milled
'Phyllanthus columnaris'
(71) thêep-tharoo god god-Taro
'Cinnamomum porrectum'
(72) pàacháa-mǒon place graveyard-gloomy 'Suregada multiflorum'

Besides depicting plants via other things discussed above, people metonymically view and then call plants according to their salient characteristics such as their appearances like shape, color, smell, surface, tissue, tastes, and amount, behavior/action,parts, usefulness/uselessness, sources, times, and possession, as shown in Table 3 with estimated percentages. 
Table 3. Categories of Metonymical Salient Characteristics of the Core and Percentage of Occurrence

\begin{tabular}{|l|c|}
\hline $\begin{array}{c}\text { Categories of } \\
\text { salient } \\
\text { characteristics }\end{array}$ & Percentage \\
\hline Appearance & 36 \\
\hline Shape & $(24)$ \\
\hline Color & $(14)$ \\
\hline Smell & $(14)$ \\
\hline Surface & $(6)$ \\
\hline Tissue & $(5)$ \\
\hline Taste & $(4)$ \\
\hline Amount & $(3)$ \\
\hline Behavior/action & 26 \\
\hline Parts & 19 \\
\hline $\begin{array}{l}\text { Usefulness/ } \\
\text { uselessness }\end{array}$ & 13 \\
\hline Sources & 3 \\
\hline Times & 2 \\
\hline Possession & 1 \\
\hline Total & $\mathbf{1 0 0}$ \\
\hline
\end{tabular}

Below is a selection of plant cores which are metonymic:

(73) bôn-khwăan shape bamboo section shape-axe 'Syzygium diospyrifolium'

(74) dææy-sôm color red-orange 'Schoutenia ovata'

(75) hว̌om-dææy smell good smell-red 'Eleutherine palmifolia (red onion)'

(76) nuan surface creamy complexioned 'Garcinia merguensis'
(77) chûm-chàm tissue

Moist

'Acronychia pedunculata'

(78) (phàk)-wăan taste

vegetable-sweet

'Sauropus albicans'

(79) sǎam-sip

amount

three-ten

'Asparagus racemosus'

(80) tittòs behavior/action

Connect

'Dasymaschalon lomentaceum'

(81) (phàk)-năam part (vegetable)-thorn

'Asparagus racemosus'

(82) yaa-sùp usefulness drug-smoke

'Nicotiapa tabacum (tobacco)'

(83) (màak)-bòk source fruit-land

'Irvingia malayana'

(84) săam-phan-pii time three-thousand-year

'Dacrydium elatum'

(85) faràn

possession

foreigner

'Psisium guajava (guava)'

\section{Plant Name Modifiers}

Statistically different from the core part, a vast majority (85 percent) of modifiers display imaginative words: 61 percent are metonymic and 24 percent are metaphorical, leaving a small number (c.15) appearing as proper names. 
The metonymic modifiers depict salient characteristics such as appearance like color, size, shape, smell, taste, tissue, surface, and amount; locations/sources; parts; procession; behaviors; postures; patterns; usefulness; effects; gender; weight; stage; age; and truth. The percentage of occurrence is provided in the following table.

Table 4. Categories of Metonymical Salient Characteristics of the Modifiers and Percentage of Occurrence

\begin{tabular}{|l|c|}
\hline $\begin{array}{l}\text { Categories of } \\
\text { salient } \\
\text { characteristics }\end{array}$ & Percentage \\
\hline Appearance & 36.60 \\
\hline Color & $(15)$ \\
\hline Size & $(7)$ \\
\hline Shape & $(6)$ \\
\hline Smell & $(3)$ \\
\hline Taste & $(2)$ \\
\hline Tissue & $(2)$ \\
\hline Surface & $(.60)$ \\
\hline Amount & 26 \\
\hline Location/sources & 16 \\
\hline Parts & 11 \\
\hline Possession & 3 \\
\hline Behaviors/actions & 1 \\
\hline Postures & 1 \\
\hline Patterns & 1 \\
\hline Usefulness & .80 \\
\hline Gender & .80 \\
\hline Weight & .80 \\
\hline Stage & .50 \\
\hline Age & .50 \\
\hline Reality & $\mathbf{1 0 0}$ \\
\hline Total & \\
\hline
\end{tabular}

A selection of plant modifiers which are metonymic is provided below:
(86) tabæ̀æk + dææy color

Lagerstroemia + red

'Lagerstroemia calyculata'

(87) campii + nóy size

Michelia + small

'Michelia floribunda'

(88) má?khǎam + pôm shape

Phyllanthus emblica + oblate

'Phyllanthus emblica'

(89) khěm + hǒom smell Ixoro finlaysoniana + good smell

'Ixoro finlaysoniana'

(90) má2-khł̌a + khǒm taste

Solanum(egg plant)+ bitter

'Solanum indicum'

(91) yaạ + khæ̌n tissue Dipterocarpus + hard 'Dipterocarpus retusus'

(92) sôm + kliay surface orange + glossy

'Citrus aurantium'

(93) phrâaw + phan-lam amount Dracaena lourieri + thousand-CLF 'Dracaena lourieri'

(94) khîilèk + pàa location Cassia + forest 'Cassia garrettiana'

(95) khamîn + tôn plant part Mohonia siamensis + stalk 'Mohonia siamensis'

(96) khîilèk + lǔan possession Cassia + royal

'Cassia siamea' 
(97) phrik + chîi-fáa behavior

Chili + point-sky (point to the sky)

'Capsicum frutescens (red)'

(98) khææ + bit posture

Fernandoa adenophylla+ twist

'Fernandoa adenophylla'

(99) kâæw + laay pattern

Murraya paniculata + variegated

'Murraya paniculata'

(100) hỉa + náam-man usefulness Dipterocarpus intricatus +oil 'Dipterocarpus intricatus'

(101) hák + phûu gender

Buchanania lanzan + male

'Buchanania lanzan'

(102) tææ + baw weight melon + light

'pickling cucumber'

(103) phrik + sòt chili + young

'Capsicum frutescens (green)'

(104) kulàap + phan-pii age rose + thousand-year

'Rhododendron arborea'

(105) tææ + cin reality melon + real

'Cucumis melo (musk melon)'

Similar to those of the core, the source domains include animals/animal parts, humans/human parts, other plants, natural items, beliefs, auspicious/ propitious things, objects and excrement. It is animals or animal parts that are mostly involved in the plant nomenclature. Other plants come second, followed closely by the other categories. The percentages of such imaginative modifiers are ranked in the following table.

Table 5. Categories of Metaphorical Source Domains of the Modifiers and Percentage of Occurrence

\begin{tabular}{|c|c|}
\hline $\begin{array}{c}\text { Categories of source } \\
\text { domains }\end{array}$ & $\begin{array}{c}\text { Percen } \\
\text { tage }\end{array}$ \\
\hline Animals/animal parts & 46 \\
\hline Other plants & 15 \\
\hline Auspicious/ Propitious things & 9 \\
\hline Objects & 8 \\
\hline Excrement & 7 \\
\hline Natural items & 7 \\
\hline Humans/human parts & 5 \\
\hline Gods/ghosts & 3 \\
\hline Total & 100 \\
\hline
\end{tabular}

A selection of modifiers that are used metaphorically is provided below:

(106) klûay + khâạ animal banana + long tailed monkey 'Orophea'

(107) dła + wâa another plant Ficus + Syzygium cumini 'Ficus auriclata'

(108) m̀̀at + ccii propitious thing Memecylon scutellatum + diamond locket 'Memecylon scutellatum'

(109) tææy + mว̌on object melon + pillow 'Citrullus vulgaris (water melon)'

(110) wâa + khîi-kwaạ excrement Syzygium + deer dung 'Syzygium fruticosum'

(111) sôm + lom natural items orange + wind 
'Aganonerion polymorphum'

(112) mìat + khon + tua-phûu human

Helicia nilagirica + human + male

'Helicia nilagirica'

(113) kradum + phǐi ghost
Clochidion rubrum + ghost
'Clochidion rubrum'

\section{Conclusion}

The paper illustrates the complex structure of plant names in Thai, the linguistic aspect that reveals the Thai folk plant taxa and conceptualization about plant life. Thai plant names reflect a primarily functional categorization centered upon the human person and the world of human experience. The plant taxa, on the other hand, are of several distinguishable ethnobiological ranks: plant kingdom, salient parts, functional plants, fruit plants, and gender. The plant kingdom is represented by a generic class term at the leading slot of the plant name structure. Under it is the salient part rank from the perception of plant parts that are salient or useful to people. Plants are also further categorized by their functions to humans such as food plants, medicinal plants, material plants, and even useless plants. Fruit plants are ranked when they provide fruit for human consumption. Gender is also marked for certain plants as well as humans.

Thai people's conceptualizations of plants as manifested in plant names afford a good deal of subtlety in their semantic structure. The nomenclatural situation is somewhat complicated due to the extensive use of imaginative language expressions. In this respect, it is the core and modifiers which are candidates to exhibit the folk conceptualizations of the world around them. In fact, it is the modifiers that relatively reveal what people think when they are talking about plants since they display more imaginative uses than the cores. The metonymically used words depict salient characteristics such as appearance like color, size, shape, smell, taste, tissue, surface, and amount; locations/sources; parts; possession; behavior; posture; pattern; usefulness; effects; gender; weight; stage; age; and truth. Modifiers etaphorically used demonstrate several source domains including animals/animal parts, humans/human parts, other plants, natural items, beliefs, auspicious/ propitious things, objects and excrement. It is animals or animal parts that mostly are involved in plant nomenclature.

Finally, the analysis of data accumulated in the plant project for Thai is an ongoing process. Much more remains to be done in order to adequately appreciate the complex nature of plant names in this language. There is a rich historical heritage encapsulated in the plant names and a knowledge about plants and their uses that is unfortunately being increasingly forgotten today. It is also worth working on a comparison of the folk ethnotaxonomic system with the scientific botanical classification to bring to light how highly Thai people developed the ability to recognize relationships among plants or, in the other words, similarities and discontinuities in nature.

\section{References}

Adams, Karen and Nancy Conklin. 1973.

Toward a Theory of Natural Classification. In Papers from the Ninth Regional Meeting of the Chicago

Linguistic Society, eds. Claudia Corum, T. Cedric Smith-Stark, and Ann Weiser, 1-10. Chicago: Chicago Linguistic Society. 
Aikhenvald, Alexandra Y. 2003. Classifiers: A Typology of Noun Categorization Devices, ch. 3, 81-97. Oxford: Oxford University Press.

Beckwith, Christopher, 1993. Class Nouns and Classifiers in Thai. In Papers from the Third Annual Meeting of the Southeast Asian Linguistics Society. Ed. Mark Alves, 11-26. Tempe, Ariz.: Program for southeast Asian Studies, Arizona State University.

Berlin, B., 1992. Ethnobiological Classification: Principles of Categorization of Plants and Animals in Traditional Societies. Princeton, NJ: Princeton University Press. Folk Systematics in Relation to Biological Classification and Nomenclature.

Berlin, B., Breeddlove, D. E. and Raven, P.H. 1973. General Principles of Classification and Nomenelature in Folk Biology. American Anthropologist 75: 214-242.

Berlin, B., Breeddlove, D. E. and Raven, P.H. 1974. Principles of Tzeltal Plant Classification: An introduction to the Botanical Ethnography of Mayan Speaking People of Highland Chiapas. New York, Academic Press.

Craig, Colette. 1986. Noun Classes and Categorization. Philadelphia: John Benjamins.

DeLancey, S. 1986. Toward a History of Tai Classifier Systems. In Noun Classes and Categorization. Ed. C. Craig. John Benjamins Publishing Company.
Dixon, R.M.W. 1986. Noun Classes and Noun Categorization in Typological Perspective. Typological Studies in Language: Noun Classes and Categorization, vol. 7. Ed. Colette Craig, 105-112. Amsterdam: John Benjamins Publishing Company.

Grinevald, Colette and Frank Seifart. 2004. Noun Classes in African and Amazonian Languages: Towards a Comparison. Linguistic Typology 8, 243-285.

Henerson, Mara. 2006. Between Lexical and Lexico-Grmmatical Classification: Nominal Classification in Sinhala. In Santa Barbara Papers in Linguistics 17. Eds. Robert Englebretson and Carol Genetti.

Hiepko, Paul. 2006. Eipo Plant Nomenclature and Classification Compared with other Folk Taxonomic Systems. Willdenowia 36, 447-453.

Jirananthanaporn, Supatra and Unchalee Singnoi. 2009. A Variation of Plant Names in Language Connecting Areas in the Lower Northern Part of Thailand. Phisanulok: Naresuan University. [in Thai]

Johnson, M. and Lakoff, G. 2003. Metaphors we live by. Chicago: University of Chicago Press.

Lakoff, George. 1987. Women, fire, and dangerous things. Chicago: University of Chicago Press.

Legère, Karsten. 2004. Vidunda People and Their Plant Names. African \& Asia, no $4,115-141$. 
Rosch, Eleanor. 1977. "Human categorization." In Warren, N. (ed.). Studies in crosscultural psychology. London: Academic, 1-49.

Royal Academy of Thailand. 1999. The Standard Thai Dictionary. Bangkok: Nanmi Book Publication.

Saul, Janice, 1965. Classifiers in Nung. Lingua 13, 278-290.

Singnoi, Unchalee. 2000. Nominal Constructions in Thai. Ph.D. Dissertation. University of Oregon.

Singnoi, Unchalee. 2005. Compound Nouns: Sciences and Arts in Thai Word Building. Bangkok: Chulalongkorn University Press. [in Thai]

Singnoi, Unchalee. 2008. Noun Classifier Constructions in Thai: A Case Study in Construction Grammar. Manusya: Journal of Humanities Vol.11.No.1., 76-90. 